\title{
Effect of Carbon Dioxide on Growth and Carbohydrate Metabolism in Sclerotium rolfsii
}

\author{
By G. KRITZMAN, I. CHET AND Y. HENIS \\ Department of Plant Pathology and Microbiology, \\ The Hebrew University of Jerusalem, Rehovot, Israel \\ (Received 5 November 1976; revised 16 January 1977)
}

\begin{abstract}
SUMMARY
Carbon dioxide at a concentration of $\mathrm{I}$ to $2 \%(\mathrm{v} / \mathrm{v})$ in air enhanced the growth rate and inhibited sclerotium formation in the fungus Sclerotium rolfsii Sacc. A $\mathrm{CO}_{2}$ concentration of $10 \%$ inhibited growth. Similar growth patterns were observed when the fungus was grown on a medium supplemented with the fungicide carboxin, which inhibits succinate dehydrogenase. A high $\mathrm{CO}_{2}$ concentration (I to $10 \%$ ) or growth on carboxin-supplemented medium caused a decrease in succinate dehydrogenase activity and significant increases in isocitrate lyase, isocitrate dehydrogenase, malate synthase and malate dehydrogenase activities. Mycelium of $S$. rolfsii grown at a high $\mathrm{CO}_{2}$ concentration contained less glyoxylate, lipids and glycogen than mycelium grown in air. It is suggested that sclerotium formation in $S$.rolfsii requires a balanced supply of carbohydrate intermediates and energy.
\end{abstract}

\section{INTRODUCTION}

It has long been realized that carbon dioxide is required for growth of bacteria, yeasts and filamentous fungi (Rockwell \& Higherberger, 1927) and its role in the biochemical processes controlling growth, fructification, sporulation and spore germination of fungi has been reviewed (Cantino \& Lovett, 1964; Niederpruem, 1965; Tabak \& Cooke, 1968). According to Cantino (1966), bicarbonate or $\mathrm{CO}_{2}$ induce multiple enzymic lesions in the tricarboxylic acid cycle, increase the activity of isocitrate dehydrogenase and cause replacement of oxidative decarboxylation of isocitrate to $\alpha$-ketoglutarate by reductive carboxylation of $\alpha$-ketoglutarate in Blastocladiella emersonii. These changes, believed to be the 'trigger' reactions in the morphogenetic response, also indicate an effect of $\mathrm{CO}_{2}$ on the glyoxylate shunt. Isocitrate is converted to succinate and glyoxylate in B. emersonii (Cantino, 1966), Fusarium (Willetts, 1972a) and Penicillium (Willetts, I972 $b$ ). In Blastocladiella, glyoxylate is further transaminated to glycine (Cantino, 1966). Another pathway of glyoxylate metabolism involves its conversion to malate by malate synthase (Willetts, i972 $a, b$; Kritzman et al., 1976). The glyoxylate shunt, however, only operates when there is a shortage of succinate (Krebs \& Lowenstein, 1960). The fungicide carboxin (5,6-dehydro-2methyl-I,4-oxathiin-3-carboxanilide), was studied by White (I97I), Georgopoulos, Alexandri \& Chrysayi (1972), Ulrich \& Mathre (1972) and Ben-Yephet, Dinoor \& Henis (I975), who found that its site of action was the succinic dehydrogenase system. In strains of Ustilago hordei tolerant to carboxin, succinate : 2,6-dichlorophenolindophenol reductase activity was inhibited while that of the alternative glyoxylate cycle increased (Ben-Yephet et al., 1975).

Recently, Kritzman et al. (1976) demonstrated a relationship between the metabolism of L-threonine via the tricarboxylic acid and glyoxylate cycles, and the morphogenesis of $S$. rolfsii. The purpose of this work was to study the effect of $\mathrm{CO}_{2}$ concentration on carbohydrate metabolism, growth and sclerotium formation in S. rolfsii. 


\section{METHODS}

Strain and growth conditions. Sclerotium rolfsii Sacc. type R ATCC26326 (Chet \& Henis, 1972) was grown at $30^{\circ} \mathrm{C}$ on a cellophane membrane in Petri plates $(8.5 \mathrm{~cm}$ diam.) containing $15 \mathrm{ml}$ of synthetic medium (SM) (Okon, Chet \& Henis, 1973). The plates were inoculated in the centre with agar discs $(0.5 \mathrm{~cm}$ diam.) from a 5-day-old colony. No degradation of the cellophane was observed when $S$. rolfsii was incubated in the presence of glucose for Io days. The following supplements (final concentrations) were separately added to the growth medium: L-threonine (Io mM); carboxin $\left(0.05 \mu \mathrm{g} \mathrm{ml}^{-1}\right)$, formulated as dust containing $75 \%$ active ingredients (Uniroyal Chemical Division, Naugatuk, Connecticut, U.S.A.).

Sclerotium rolfsii was grown under controlled atmospheres containing different concentrations of $\mathrm{CO}_{2}$ in BBL anaerobic jars. Radial linear growth was measured at intervals. Mycelial dry weight was determined after separating the mycelium from the cellophane membrane with tweezers and drying at $80^{\circ} \mathrm{C}$ for $24 \mathrm{~h}$.

Enzyme assays. Mycelium (about $3 \mathrm{~g}$ wet wt) was homogenized in $3 \mathrm{ml}$ buffer for I min at $4{ }^{\circ} \mathrm{C}$ using an Ultra-Turrax homogenizer (Janke \& Kunkel K.G., Staufen, West Germany). The homogenate was centrifuged at $\mathrm{I} 8000 \mathrm{~g}$ for $20 \mathrm{~min}$ at $4{ }^{\circ} \mathrm{C}$. Unless otherwise stated, low molecular weight compounds were removed from the supernant fluid by overnight dialysis against distilled water at $4{ }^{\circ} \mathrm{C}$. The protein content of the crude extract was determined with the Folin phenol reagent (Lowry et al., 1951). Enzyme activities in the crude extract were determined by published methods: isocitrate dehydrogenase, EC. I. I.I.42 (Wang, 1955); isocitrate lyase, EC. 4.I.3.I, and glyoxylate dehydrogenase, EC. I.2.I.I7 (Maxwell \& Bateman, I968b); succinate dehydrogenase, EC. I.3.99.I (Ulrich \& Mathre, 1972); malate synthase, EC. 4.I.3.2 (Maxwell \& Bateman, I968a); malate dehydrogenase, EC. I. I . I.37 (Akira, 1969).

Chemical analysis. Oxalate and glyoxylate production were determined according to Maxwell \& Bateman (I968b). Other analytical methods were: lipid (Chiang, Gessler \& Lowry, 1957); glycogen (Van Handel, 1965); glucose (Sigma Technical Bulletin no. 510, I973); and glucosamine (Elson \& Morgan, I933). Hyphal wall preparation and its chemical analysis was carried out as described by Chet, Henis \& Mitchell (1967).

L-Threonine uptake and transport. For studies of the uptake and transport of ${ }^{2}-\left[{ }^{14} \mathrm{C}\right]-$ threonine, 48-h-old cultures grown on cellophane were transferred to Petri plates containing Io $\mathrm{ml}$ liquid medium and $4 \mathrm{~mm}$ glass beads ( 80 per plate) to support the cellophane. Labelled threonine (specific activity $10 \mathrm{mCi} \mathrm{mol}^{-1}$; The Radiochemical Centre, Amersham) was used at a final concentration in the growth medium of $0 \cdot \mathrm{I} \mu \mathrm{Ci} \mathrm{ml^{-1 }}$ and the cultures were incubated for $2 \mathrm{~h}$. The mycelium was then separated from the cellophane membrane with tweezers and washed with $0 \cdot \mathrm{I}$ M-phosphate buffer $\mathrm{pH} 7 \cdot 0$ until no radioactivity could be detected in the buffer. The washed mycelium was dried at $80^{\circ} \mathrm{C}$ for $24 \mathrm{~h}$ and weighed, and its radioactivity was measured in a Packard Tri-Carb scintillation spectrometer (model 3330).

Carbon dioxide uptake and transport. For studies of the uptake and transport of ${ }^{14} \mathrm{CO}_{2}$, 48-h-old cultures grown on cellophane were transferred for $6 \mathrm{~h}$ to $\mathrm{BBL}$ anaerobic jars (no. 32I60-IO) containing I \% (v/v) $\mathrm{CO}_{2}$ supplemented with ${ }^{14} \mathrm{CO}_{2}$ [2 $\mathrm{mCi}$ (3 1 air) $\left.{ }^{-1}\right]$. Labelled $\mathrm{CO}_{2}$ was produced from sodium $\left[{ }^{14} \mathrm{C}\right]$ carbonate (specific activity $60 \mathrm{mCi} \mathrm{mmol}{ }^{-1}$; The Radiochemical Centre, Amersham) by addition of conc. HCl. After incubation, the mycelium was separated from the cellophane, washed, dried, weighed and its radioactivity was measured as described above. 


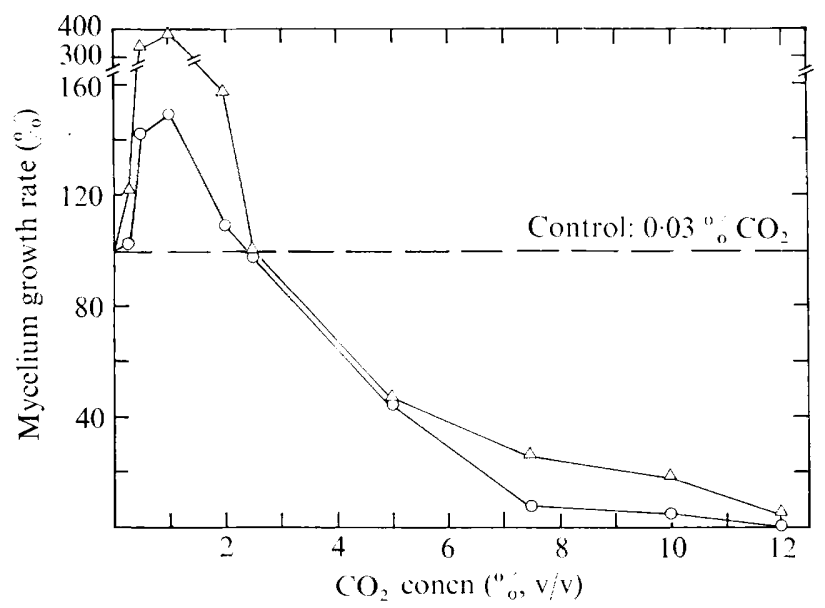

Fig. I. Radial growth rates of $S$. rolfsii in the presence of different $\mathrm{CO}_{2}$ concentrations when grown on SM $(O)$ and on SM plus Io mM-L-threonine $(\triangle)$. Results are expressed as percentages of the growth rates in air $\left(0.03 \% \mathrm{CO}_{2}\right)$. Points represent the mean of $\mathrm{I} 2$ determinations from three independent experiments; all s.E.M. lie within the symbols.

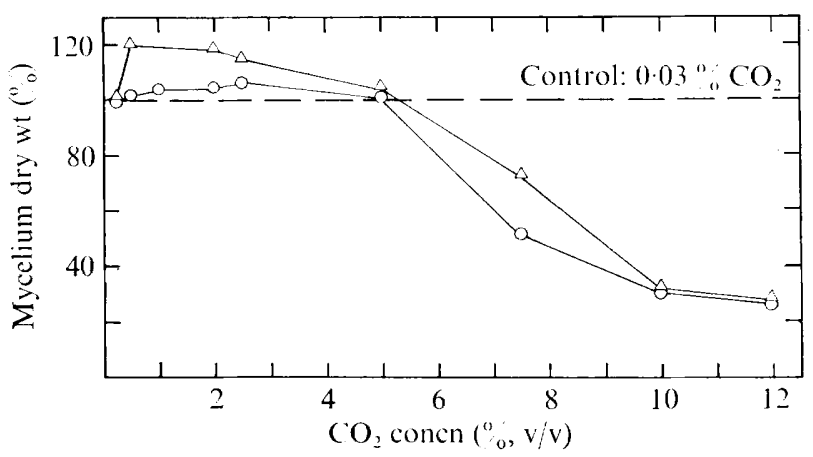

Fig. 2. Growth of $S$. rolfsii mycelium (dry wt) in the presence of different $\mathrm{CO}_{2}$ concentrations on SM $(O)$ and on SM plus Io mM-L-threonine $(\triangle)$. Results are expressed as percentages of the mycelium growth in air $\left(0.03 \% \mathrm{CO}_{2}\right)$. Points represent the mean of $\mathrm{I} 2$ determinations from three independent experiments; all s.E.M. lie within the symbols.

\section{RESULTS AND DISCUSSION}

Sclerotium rolfsii was grown in atmospheres containing different amounts of $\mathrm{CO}_{2}$. After ro $\mathrm{h}$ incubation in an atmosphere enriched with 0.5 to $2 \%(\mathrm{v} / \mathrm{v}) \mathrm{CO}_{2}$, mycelium growth rates had increased up to $400 \%$ compared with cultures grown in air (Fig. I). The average growth rate of cultures grown in air on SM was $0.78 \mathrm{~mm} \mathrm{~h}^{-1}$ compared with $0.22 \mathrm{~mm} \mathrm{~h}^{-1}$ for cultures grown in air on SM plus L-threonine. With $\mathrm{I} \% \mathrm{CO}_{2}$ the growth rates increased to $\mathrm{I} .57 \mathrm{~mm} \mathrm{~h}^{-1}$ and $0.63 \mathrm{~mm} \mathrm{~h}^{-1}$, respectively. Increasing the amount of $\mathrm{CO}_{2}$ also induced more branched aerial mycelium. The presence of Io $\mathrm{mM}-\mathrm{L}$-threonine increases branching of lateral hyphae and enhances sclerotium formation (Henis, Okon \& Chet, 1973; Kritzman et al., 1976). Our present findings confirm earlier observations on the lack of correlation between hyphal growth rate and sclerotium formation (Chet \& Henis, I968).

The mass of $S$. rolfsii mycelium increased significantly in the presence of 0.5 to $2.5 \%$ $\mathrm{CO}_{2}$, with or without L-threonine, and sharply declined in the presence of $7.5 \% \mathrm{CO}_{2}$ 


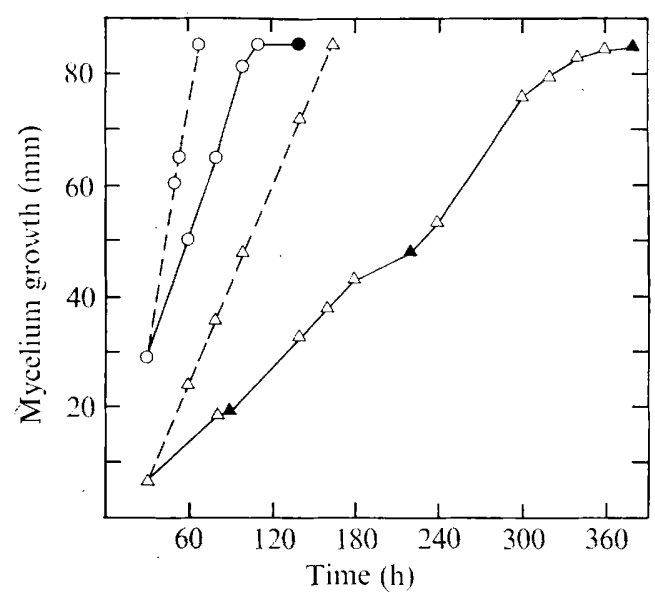

Fig. 3. Linear growth rate of $S$. rolfsii on SM(O-O); SM in the presence of $1 \% \mathrm{CO}_{2}(\mathrm{O}---\bigcirc)$; SM plus Io mM-L-threonine $(\triangle-\triangle)$; SM plus Io mM-L-threonine in the presence of $\mathrm{I} \% \mathrm{CO}_{2}$ $(\triangle---\triangle)$. Sclerotium formation is indicated by $\Delta$ or $\bullet$. Points represent the mean of 15 determinations from three independent experiments; all s.E.M. lie within the symbols.

(Fig. 2). When cultures grown in air were transferred to atmospheres containing $0.3 \%$ or more $\mathrm{CO}_{2}$ at any time before the appearance of sclerotial initials, sclerotium formation was totally inhibited (Fig. 3). This indicates that $\mathrm{CO}_{2}$ inhibits sclerotium formation even in the presence of L-threonine.

Mycelium of $S$. rolfsii grown either under an atmosphere enriched with I \% $\mathrm{CO}_{2}$ or in the presence of carboxin, with or without L-threonine, showed reduced succinate dehydrogenase activity (Table I). Cell-free extracts of $S$. rolfsii mycelium, grown on SM or on SM plus L-threonine in the presence of $\mathrm{I} \% \mathrm{CO}_{2}$, had, respectively, $38 \%$ and $65 \%$ of the succinate dehydrogenase and $147 \%$ and $208 \%$ of the isocitrate dehydrogenase activities of similar preparations from air-grown fungus. Similar results were obtained with mycelium grown in air on carboxin-supplemented media.

No differences in isocitrate lyase activity were detected in any of the cell-free extracts of $S$. rolfsii grown on SM, SM plus $\mathrm{CO}_{2}$ or SM plus L-threonine. However, the activity in extracts of the fungus grown on SM plus L-threonine and incubated under an atmosphere containing $\mathrm{I} \% \mathrm{CO}_{2}$ was $\mathrm{I} \cdot 9$ times higher than that in extracts of the fungus grown in air. The addition of $\mathrm{CO}_{2}$, L-threonine or both caused a reduction in the glyoxylate content of the fungal mycelium, but significantly increased the activity of malate synthase and malate dehydrogenase. The activity of these two enzymes was similarly increased in mycelium grown on a carboxin-supplemented medium (Table I).

The activity of glyoxylate dehydrogenase and the amount of oxalate produced were much reduced after $\mathrm{Io} \mathrm{h}$ incubation in the presence of $\mathrm{I} \% \mathrm{CO}_{2}$ (Table $\left.\mathrm{I}\right)$. There was a correlation of $r=0.99$ between glyoxylate dehydrogenase activity and the rate of oxalate production [ $\mu \mathrm{g} \mathrm{h}^{-1}\left(\mathrm{mg}\right.$ mycelium dry wt) ${ }^{-1}$ ], $y=0.0667+6 \cdot 3 \mathrm{I} 68 x$.

Kritzman et al. (1976) suggested that hyphal morphogenesis and formation of sclerotia in $S$. rolfsii require an increased supply of carbohydrate intermediates and energy and that these are mainly supplied by the glyoxylate pathway. Spore formation and fruiting in other fungi are also affected by atmospheres with increased amounts of $\mathrm{CO}_{2}$ (Tabak \& Cooke, I968). According to Plunkett (I954, I956), $\mathrm{CO}_{2}$ accumulation inhibits sporophore development in Collybia velutipes. Niederpruem (1963) found an increase in the vegetative growth 


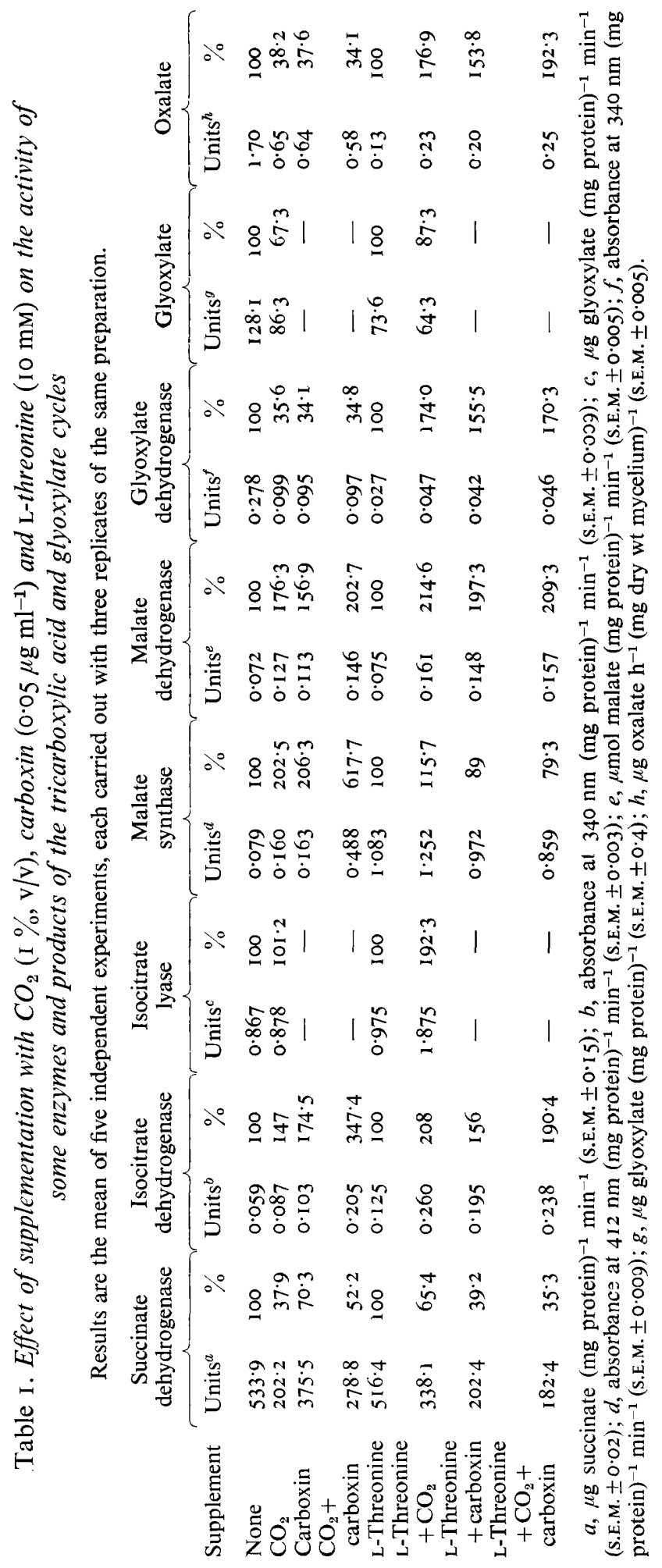


Table 2. Effect of $\mathrm{CO}_{2}(\mathrm{I} \%, \mathrm{w} / \mathrm{v})$ on the amounts of cell wall, protein, glycogen, free glucose and lipids in $S$. rolfsii grown on $S M$ with or without $\mathrm{L}-$ threonine (IO $\mathrm{mM}$ )

Results are the mean of five independent experiments, each carried out with three replicates of the same preparation.

$\begin{array}{lccccc}\text { Supplement } & \text { Cell wall } & \text { Protein } & & \text { Free } & \text { Glycogen } \\ \text { None } & 68.29 & 7.87 & 0.238 & \text { glucose }^{d} & \text { Lipid }^{e} \\ \mathrm{CO}_{2} & 46.80 & 8.72 & 0.069 & 0.0033 & 0.04 \\ \text { L-Threonine } & 73.33 & 8.78 & 0.113 & 0.0066 & 0.03 \\ \text { L-Threonine }+\mathrm{CO}_{2} & 68.88 & 9.08 & 0.053 & 0.001 \mathrm{I} & 0.08 \\ & & & \end{array}$

$a$, Dry wt, as a percentage of dry wt mycelium (s.E.M. \pm 0.05$) ; b$, percentage of dry wt mycelium (s.E.M. \pm $0.0 \mathrm{I}) ; c, \mathrm{mg}$ glucose (mg dry wt mycelium) ${ }^{-1}$ (S.E.M. \pm 0.003$) ; d, \mathrm{mg}$ glucose (mg dry wt mycelium) ${ }^{-1}$ (S.E.M. \pm $0.000 \mathrm{I}) ; e, \mathrm{mg}$ lipid (mg dry wt mycelium) ${ }^{-1}$ (s.E.M. \pm 0.005$)$.

of Schizophyllum commune in sealed chambers, but an inhibition of fruiting: this inhibition was reversed on aeration.

Bettelhein \& Gay (1963) suggested that, in yeast, sporulation increased when a high level of glyoxylate was formed. Acetate alone, however, did not supply enough energy and intermediates to meet the level required for sporulation. We have found that the presence of carbon dioxide also caused a reduction in the amounts of mycelial glucose, reserve materials (glycogen, lipids) and wall material, but had no effect on the protein content (Table 2). There were no qualitative or quantitative differences in the chemical constituents (carbohydrates, proteins, lipids and ash) detected in walls of $S$. rolfsii grown in I \% $\mathrm{CO}_{2}$ or in air. The relatively high amount of lipid present in $S$. rolfsii grown on $\mathbf{L}$-threonine can be explained by the direct incorporation of L-threonine into the lipid fraction. This was demonstrated by the uptake of labelled threonine into the lipid fraction (2319 c.p.m. $\mathrm{mg}^{-1}$ ) during $2 \mathrm{~h}$ incubation.

When incubated in an atmosphere containing $\mathrm{I} \% \mathrm{CO}_{2}$ supplemented with labelled $\mathrm{CO}_{2}$, $S$. rolfsii mycelium incorporated 734 c.p.m. (mg dry wt mycelium) $)^{-1} \mathrm{~h}^{-1}$ on SM and 2135 c.p.m. (mg dry wt mycelium) $)^{-1} \mathrm{~h}^{-1}$ on SM plus L-threonine. The distribution of radioactivity in the SM-grown mycelial fractions [c.p.m. (mg dry wt mycelium) ${ }^{-1}$ ] was as follows: wall, 76; material insoluble in trichloroacetic acid, I37; material soluble in trichloroacetic acid, 1975. The radioactivities of the oxalic acid fractions excreted by $S$. rolfsii grown on SM and SM plus L-threonine in the presence of ${ }^{14} \mathrm{CO}_{2}$ were 1078 and 354 c.p.m. (mg dry wt mycelium $)^{-1}$ respectively. When grown on $\mathrm{SM}$ in $\mathrm{I} \% \mathrm{CO}_{2}, \mathrm{~S}$. rolfsii produced $2 \cdot 8$ times more oxalic acid than when grown on SM plus L-threonine (Table I). Similarly, the radioactivity of the oxalic acid produced in the presence of ${ }^{14} \mathrm{CO}_{2}$ on $\mathrm{SM}$ was three times that produced on L-threonine.

A scheme based on the data presented, which would explain the biochemical basis of the morphogenetic effect of $\mathrm{CO}_{2}$ on $S$. rolfsii, is shown in Fig. 4. According to this scheme, $\mathrm{CO}_{2}$ is not only incorporated into cell constituents but also inhibits the tricarboxylic acid cycle, thus affecting both the type and amounts of carbohydrate intermediates. The fungus overcomes the partial inhibition of the tricarboxylic acid cycle by operating the alternative glyoxylate pathway. In this respect, the effect of $\mathrm{CO}_{2}$ on the tricarboxylic acid and glyoxylate cycles is similar to that of carboxin which inhibits succinate:2,6-dichlorophenolindophenol reductase (Ulrich \& Mathre, 1972) and sclerotium formation. Only one of the two possible metabolic pathways was operating (glyoxylate shunt, Fig. 4), and no sclerotia were formed in the presence of high $\mathrm{CO}_{2}$ concentrations. A few sclerotia were formed on SM and, in that case, only one pathway was operating (the tricarboxylic acid cycle, Fig. 4). Increasing 

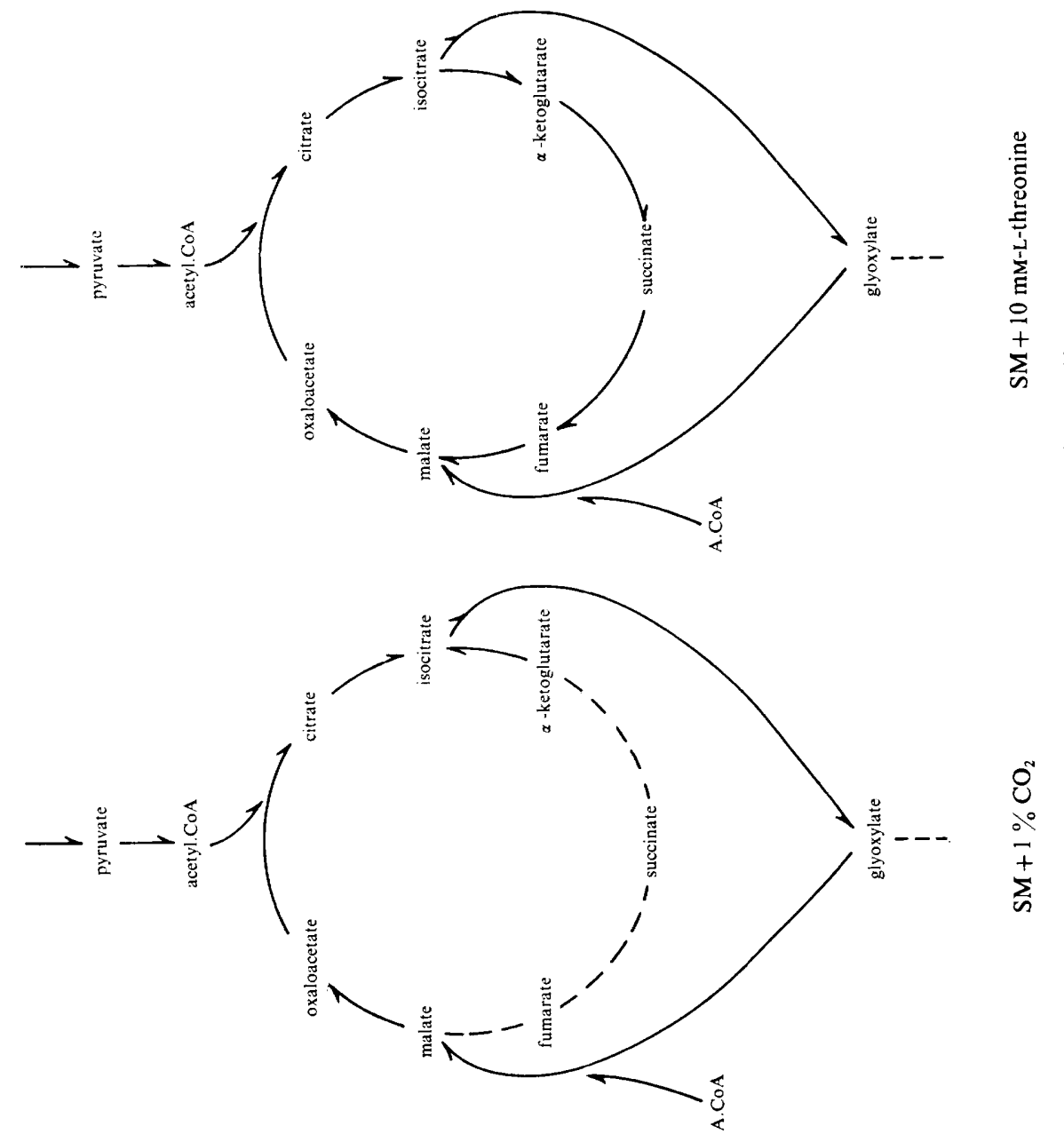

:
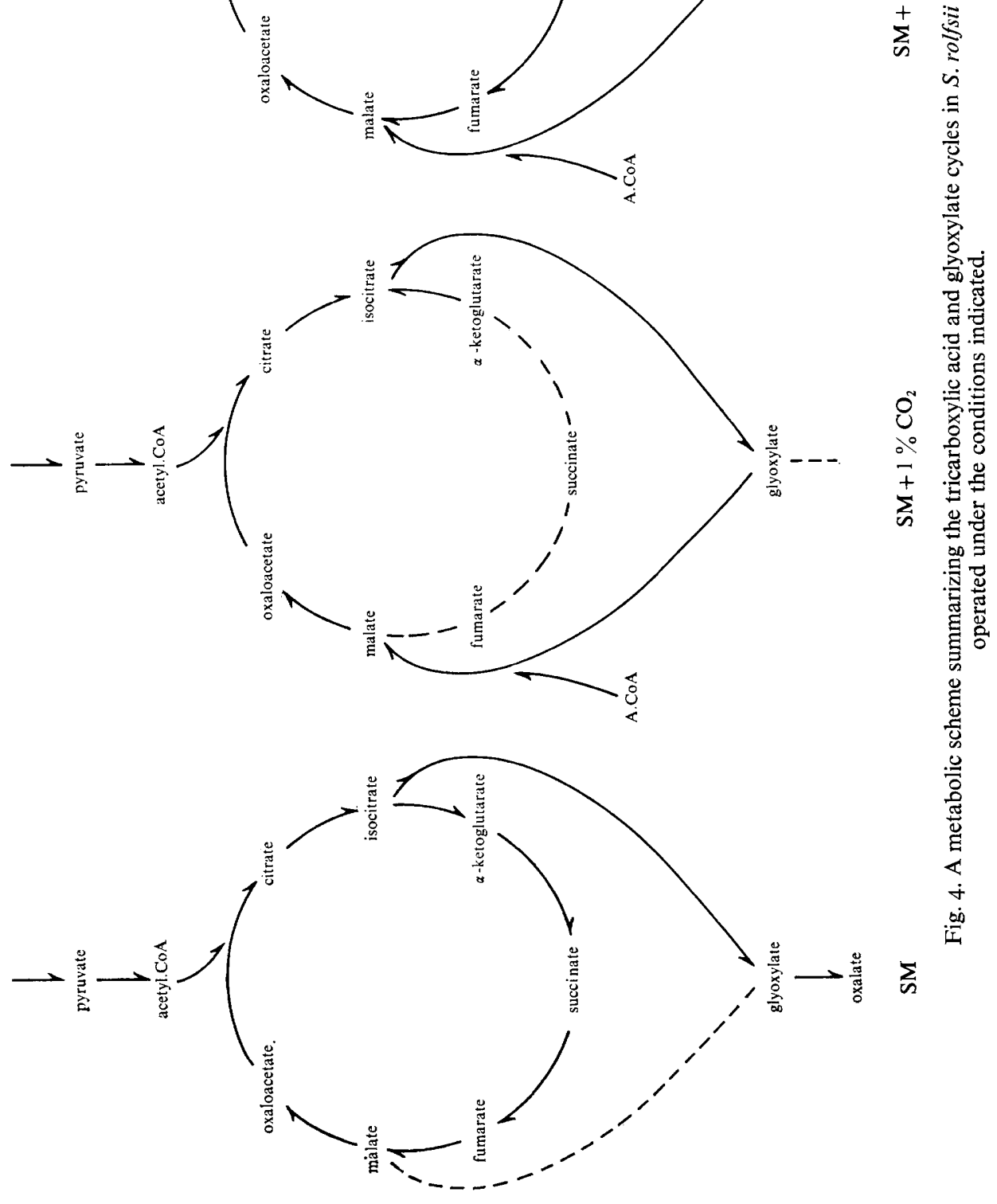
numbers of sclerotia were formed in the presence of L-threonine which activates both the glyoxylate and the tricarboxylic acid cycles, while inhibiting the production and release of oxalic acid by this fungus (Kritzman et al., 1976).

The data indicate that the simultaneous operation of the tricarboxylic acid and glyoxylate cycles in $S$. rolfsii supplies increased levels of energy and carbohydrate intermediates at a balance which may be essential for sclerotium formation.

\section{REFERENCES}

AKIRA, Y. (1969). L-Malate dehydrogenase. Methods in Enzymology, XIII, I4I-I45.

BEN-YePHET, Y., DinOoR, A. \& HENIS, Y. (I975). The physiological basis of carboxin sensitivity and tolerance in Ustilago hordei. Phytopathology 65, 936-942.

Bettelhein, K. A. \& GAY, J. A. (1963). Acetate-glyoxylate medium for the sporulation of Saccharomyces cerevisiae. Journal of Applied Bacteriology 26, 23 I-244.

Cantino, E. C. (I966). In The Fungi, An Advanced Treatise, vol. II, pp. 283-337. Edited by G. C. Ainsworth and A. S. Sussman. New York: Academic Press.

Cantino, E. C. \& LovetT, J. S. (I964). Non-filamentous aquatic fungi: model systems for biochemical studies of morphological differentiation. In Advances in Morphogenesis, vol. 3, pp. 33-93. Edited by M. Abercrombie and J. Brachet. New York: Academic Press.

CHET, I. \& HeNIs, Y. (1968). The control mechanism of sclerotial formation in Sclerotium rolfsii (Sacc.). Journal of General Microbiology 54, 231-236.

CHET, I. \& HENIS, Y. (1972). The response of two types of Sclerotium rolfsii to factors affecting sclerotium formation. Journal of General Microbiology 79, $147-150$.

Chet, I., Henis, Y. \& Mitchell, R. (1967). Chemical composition of hyphal and sclerotial walls of Sclerotium rolfsii Sacc. Canadian Journal of Microbiology 13, 137-I4I.

Chiang, S. P., Gessler, C. F. \& Lowry, O. H. (1957). Calorimetric Determination of Extracted Lipids, An adaptation of microgram amount. Texas: Cerumen School of Aviation Medicine, U.S.A.F.

ELSON, L. A. \& MORGAN, W. Y. (1933). A colorimetric method for the determination of glucosamine and chondrosamine. Biochemical Journal 27, 1824-1828.

Georgopoulos, S. G., AleXandri, E. \& ChrYSAYI, M. (1972). Genetic evidence for the action of oxathiin and thiazole derivatives on the succinic dehydrogenase system of Ustilago maydis mitochondria. Journal of Bacteriology 110, 209-217.

HENIS, Y., OKON, Y. \& CHET, I. (1973). The relationship between early hyphal branching and sclerotial formation in Sclerotium rolfsii. Journal of General Microbiology 79, $147-150$.

Krebs, H. A. \& Lowenstein, J. M. (1960). In Metabolic Pathways, vol. I, I 29-203. Edited by D. M. Greenberg. New York: Academic Press.

Kritzman, G., OKon, Y., CHET, I. \& Henis, Y. (1976). Metabolism of L-threonine and its relationship to sclerotium formation in Sclerotium rolfsii. Journal of General Microbiology 95, 78-86.

Lowry, O., Rosebrough, N. J., FARR, A. L. \& RANDAlL, R. J. (I95I). Protein measurement with the Folin phenol reagent. Journal of Biological Chemistry 193, I65-I75.

Maxwell, D. P. \& Bateman, D. F. (1968a). Glucose catabolism in Sclerotium rolfsii. Phytopathology 58, $1630-1634$.

MaXwell, D. P. \& Bateman, D. F. (I968b). Oxalic acid biosynthesis by Sclerotium rolfsii. Phytopathology 58, 1635-1642.

NieDERPRUEM, D. J. (1963). Role of carbon dioxide in the control of fruiting of Schizophyllum commune. Journal of Bacteriology 85, $1300-1308$.

NieDerpruem, D. J. (1965). In The Fungi, An Advanced Treatise, vol. I, pp. 169-300. Edited by G. C. Ainsworth and A. S. Sussman. New York: Academic Press.

OKon, Y., CHET, I. \& HeNIS, Y. (1973). Effect of lactose, ethanol and cycloheximide on the translocation pattern of radioactive compounds and on sclerotium formation in Sclerotium rolfsii. Journal of General Microbiology 74, 25I-258.

PlunkeTt, B. E. (1954). The aeration complex of factors and fruit-body formation in pure cultures of Hymenomycetes. VIII Congress of International Botany, Paris. Rapp and Comm. Sect. 18-20, pp. IOI-IO2.

PlunketT, B. E. (1956). The influence of factors of the aeration complex and light upon fruit-body formation in pure cultures of an agaric and polypore. Annals of Botany, N.S. 20, 563-586.

RockwELl, E. \& Higherberger, J. H. (1927). The necessity of carbon dioxide for the growth of bacteria, yeasts and molds. Journal of Infectious Diseases 40, 438-446.

Sigma TeChnical Bulletin No. 5IO. (1973). London: Sigma Chemical Co.

TABAK, H. H. \& CoOKE, W. B. (I968). The effects of gaseous environments on the growth and metabolism of fungi. Botanical Review 34, I26-252. 
Ulrich, J. T. \& MAthre, D. E. (1972). Mode of action of oxathiin systemic fungicides. V. Effect on electron transport system of Ustilago maydis and Saccharomyces cerevisiae. Journal of Bacteriology 110, 628-632.

VAN Handel, E. (1965). Estimation of glycogen in small amounts of tissue. Analytical Biochemistry $\mathbf{x}$, 256-265.

WANG, T. P. (I955). Isccitric dehydrogenase. Methods in Enzymology II, 652-655.

WhITE, G. A. (I97I). A potent effect of 1,4 -oxathiin systemic fungicides on succinate oxidation by a particulate preparation from Ustilago maydis. Biochemical and Biophysical Research Communications 44, I 2I 2-I 2 I9.

WILlETtS, A. J. (1972a). Metabolism of threonine by penicillia: growth on threonine as a sole carbon and nitrogen source. Journal of General Microbiology 73, 71-83.

WiLletTs, A. J. (1972 $b$ ). Metabolism of threonine by Fusarium growth on threonine as the sole carbon and nitrogen source. Antonie van Leeuwenhoek 38, 591-603. 